\title{
Full Scale Test of Smoke Leakage from Doors of a Highrise Apartment
}

\section{OSAMI SUGAWA and IICHI OGAHARA}

Center for Fire Science and Technology

Science University of Tokyo

2641 Yamasaki Noda-shi, 278 Chiba, Japan

\section{KAZUO OZAKI}

Mitsui Fudousan (Mitsui Real Estate) Co., Ltd.

2-1-1 Nihonbashi Muromachi Chuoku 103 Tokyo, Japan

\section{HIROOMI SATO}

Building Engineering Department, Kajima Corporation

2-19-1 Tobitakyu, Chofu-shi 182 Tokyo, Japan

\section{ISAO HASEGAWA}

Research Division of Mitsui Construction Co., Ltd.

518-1 Komagi Nagareyama, 270-01 Chiba, Japan

\section{ABSTRACT}

Check of smoke leakage of an entrance door, class A fire door, for highrise apartment was carried out in a full scale model using a model fire source which was designed to smolder 1 hour and then to flame. The door openable inward and outward with and without air tight material were used. A total 13 types of experimental conditions was carried out with major variables of door situation (open or closel and of pressure difference between fire room and corridor. Concentrations of smoke, gas, and smoke particles, pressure, temperatures, and weight of fire source were measured. No difference in smoke leakage performance between doors openable inward and outward was obtained. Smoke and combustion gas in corridor were hardly observed when the entrance door was closed, therefore it suggests clearly that the middle corridor is safe enough as an evacuation route when the door was closed.

KEY WORDS; FULL SCALE TEST, SMOKE LEAKAGE FROM DOOR, CLASS A FIRE TIGHT DOOR, SMOKE PARTICLES, FIRE DETECTOR, SMOLDERING

1. Introduction and objective of this Work

The highrise apartment for this study has a star shape arrangement with middle corridor and veranda as two evacuation routes. There is danger of hot smoky gas filling in the middle corridor as if combustion gas comes out through/around the entrance door. It is very plausible that the residents would take the middle corridor as an evacuation route because they know it well. Therefore, it is necessary and important to keep the middle corridor free from fire products.

The objectives of this experimental study is to check the doors performance against smoke leakage under the conditions of pressure difference given between the fire room and corridor with using an early stage of a fire source which grows from smoldering to flaming. Fire detectors performance is also examined. 
2. Fire scenario and Model fire source

The fire statistics shows that about $26 \%$ of fires is caused by a cigarette and about $29 \%$ of first item of fire development is occupied by a bedding and a sofa. The death rate in midnight is higher than the other period for resident fire. Concern with these situations, the fire scenario to follow is set. A lighted cigarette fell on a sofa and makes smoldering combustion first, then flaming which develops to involve the wallpaper and finally to flashover. The first two stages of the fire, about 1 hour smoldering and $10 \mathrm{~min}$ flaming, are adopted for this study as the model of an early development of fire.

\section{(a) mockup cushion}

Babrauskas(ref.1) reported that the optical smoke concentration (Cs) of $1 / \mathrm{m}$ was generated from a standard chair in $28.3 \mathrm{~m}^{3}$ volume of fire room. Kawagoe and Mizuno(ref.2) also reported that a cushion gave 1-1.2/m of Cs. A sofa and two loungers, are like a bedding, were adopted as the first item of a fire. The smoke concentration from them is about 4-5 times greater than it from a chair. The volume of fire room is about $42.5 \mathrm{~m}^{3}$ then the smoke load is expected to be about $200 \mathrm{~m}^{-1} \cdot \mathrm{m}^{3}$. Several kinds of mockup cushions fire had been tried in preliminary tests, and its smoke evolution repeatability was especially tested. The fire source adopted finally was consists of $60 \mathrm{~cm} \mathrm{X} 60 \mathrm{~cm} \mathrm{X} 6 \mathrm{~cm}(\mathrm{~T})$ of polyurethane foam of about $240 \mathrm{~g}$, cotton batting of $160 \mathrm{~g}$, and thick cotton cloth of $270 \mathrm{~g}$. It gave the smoldering duration of about 60 $\mathrm{min}$ and $\mathrm{Cs} \mathrm{V}$ of about $70 \mathrm{~m}^{-1} \cdot \mathrm{m}^{3}$. Thus, three cushions were used simultaneously to give the designed smoke load. The average mass loss rate of a chair is about $6-8 \mathrm{~g} / \mathrm{sec}$ for its first $10 \mathrm{~min}$ (ref.1,2) flaming. Therefore, the heat release rate of about 100 $\mathrm{Kw}$ for 10 min was planned to give by the alcohol burning.

(b) Full size fire source

A sofa of about $22.7 \mathrm{~kg}$, two loungers of 9.3 and $8.8 \mathrm{~kg}$, a wooden side table of about $8 \mathrm{~kg}$, a wooden magazine rack of $0.5 \mathrm{~kg}$, a $14^{\prime} \mathrm{TV}$ set with wood frame, carpet of $4 \mathrm{mX} 4.5 \mathrm{~m}$, wall- and ceiling paper, and a book stand of $90 \mathrm{~cm}$ width and $120 \mathrm{~cm}$ height with about $150 \mathrm{~kg}$ of books were adopted.

\section{Experimental}

Monthly average wind velocities in Tokyo area are about 2.9 , $3.3,3.0$, and $2,8 \mathrm{~m} / \mathrm{sec}$ for Jan., May, Aug., and Oct.. Thus 3 $\mathrm{m} / \mathrm{sec}$ was adopted as an average wind velocity for estimation of the pressure difference between fire room and middle corridor. The corridor is semi-enclosed, therefore, coefficients of upwind and downwind pressures are reduced to half of them, compared with those of ordinary case. About $0.5 \mathrm{mmAq}$ of pressure difference was given between fire room and middle corridor. The plan and vertical views of the facility is shown in Fig. 1. The total ventilating openings was controlled to adjust to the respective value of the real one by sealing off with tapes and putty.

Door 1 was a wooden partition door. Door 2 (inward openable) and door 3 (outward openable) are class A fire door. Leakage characteristics of the door was tested preliminary, and gave the performance of $Q=0.22 \cdot P^{0.76}(0.5 \leqq P<20)$, where $Q$ is ventilation air volume $\left(\mathrm{m}^{3} / \mathrm{h}\right)$ and $P$ is positive pressure difference $\left(\mathrm{kg} / \mathrm{m}^{2}\right)$ between inside and outside. 
In order to measure the smoke movement and concentration, extinction beams were set in as partly illustrated in Fig. 2 . Temperature were measure by $\mathrm{K}$-type thermocouples. The sample gas was introduced about $10 \mathrm{~cm}$ below the ceiling and was sent into the analysers. $\mathrm{CO}, \mathrm{CO} 2$ and $\mathrm{O} 2$ gas concentrations were measured. The sample gas was then returned back to the respective section. Two kinds of smoke detectors, ionization (I.S.D.) and scattering type (L.S.D.) which were modified to give analog outputs, and also two kinds of heat detectors, rate of rise heat and fixed temperature type were employed. Simple weighing system was used which consists of load cells with a water jacket and of a bed or a platform. Outputs from many sensors were recorded every $2 \mathrm{~min}$. The smoke filling and movements were also observed and recorded by camera and two sets of video system.

Experimental conditions of door openings, fire source, and pressure difference are shown in Table 1.
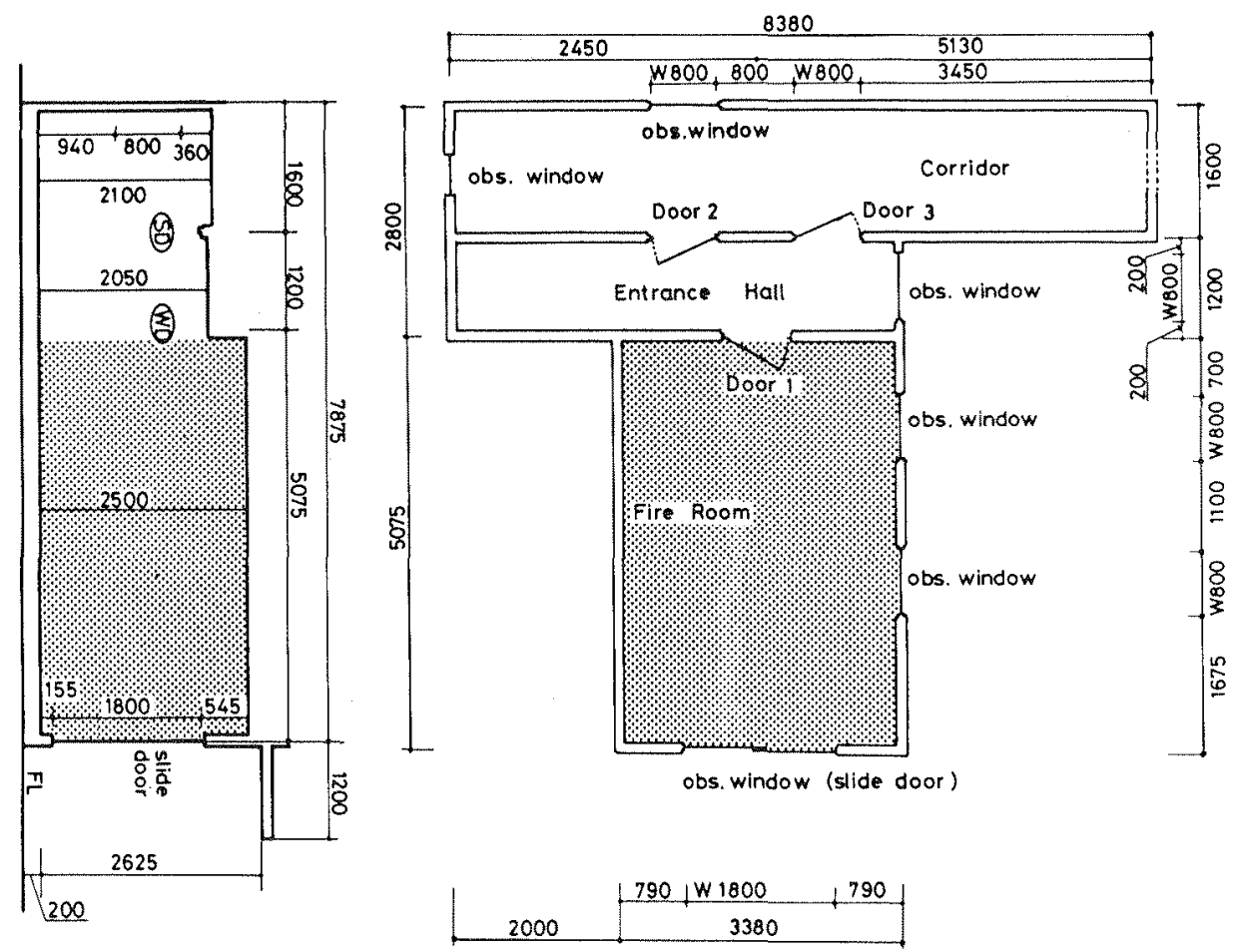

\footnotetext{
Figure 1 The plan view and vertical view of the facility for this experimental study. The $\mathrm{mm}$ unit is adopted for scale.
}

4. Results and Discussion

(a) Mockup Cushions Fire

A pill of METHENAMINE with an electric heater which activated for 10-15 sec was used for ignition method.

The smoldering area on the mockup cushion increased circular- 
ly at the rate of about $1 \mathrm{~cm} / \mathrm{min}$ in radius, and about $30 \mathrm{~min}$ after, burning zone developed into the foam. The typical results for weight loss versus time are shown in Fig.3. Each plot shows a remarkable tendency. to cluster the curve. This indicates that every fire source gave almost same amounts of smoke, gas, and heat at the almost same release rates. Almost steady state of smoldering combustion at the rate of $15.5 \mathrm{~g} / \mathrm{min}$ of three cushions was observed for 30-65 min. After $60 \mathrm{~min}$, the alcohol was ignited and gave the heat release rate of about $107 \mathrm{~kW}$ for $10 \mathrm{~min}$.

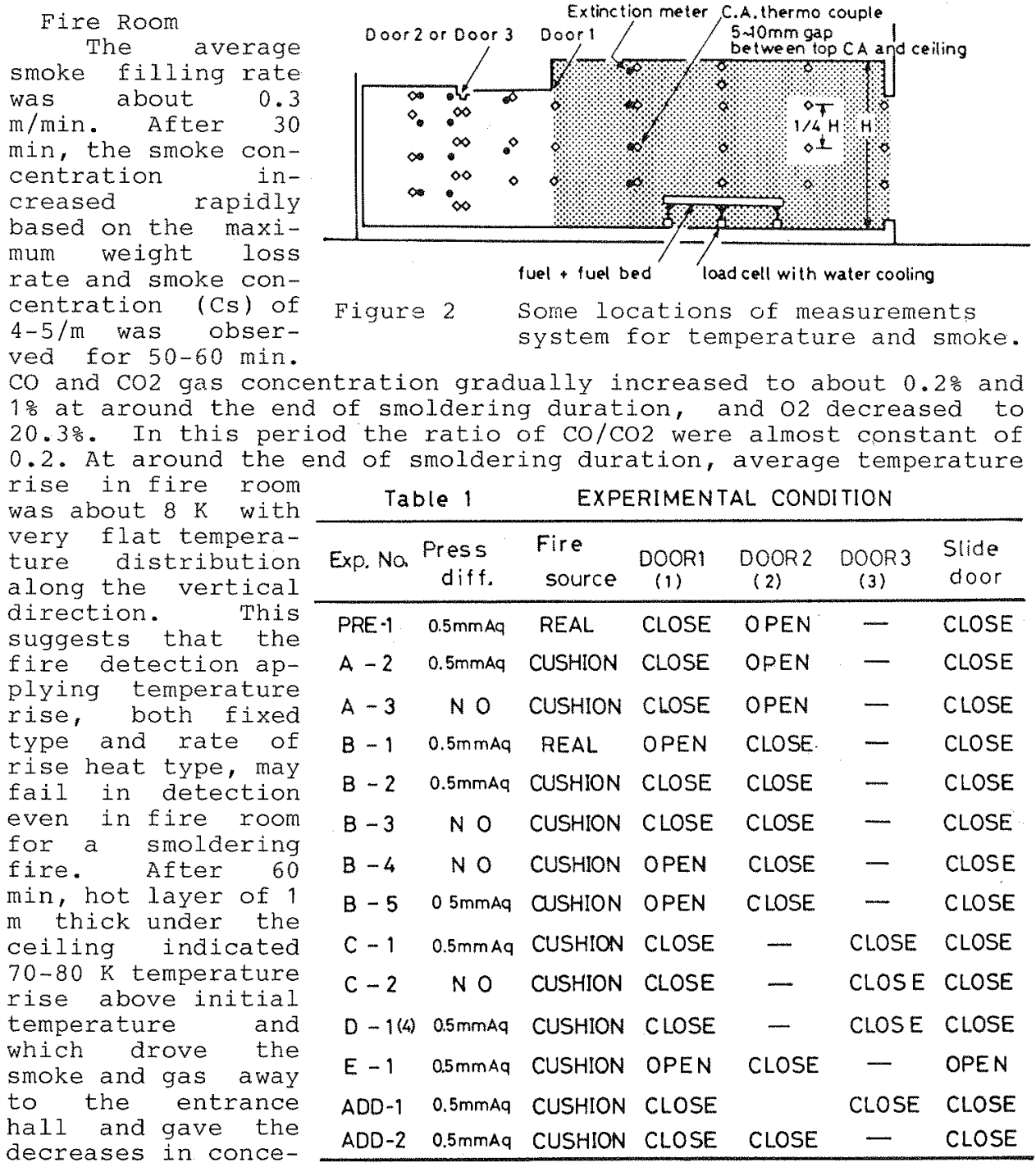
ntrations of smoke and gas. Little

wooden door(1) inward openable (2) outward openable (3)

without air light material (4) 
difference in smoke and gas concentrations was found independent of door 1 opened or closed. Table 2 and 3 show the concentrations of smoke and $\mathrm{CO}, \mathrm{CO} 2$ and $\mathrm{O} 2$ gas in fire room, entrance hall, and middle corridor.

Entrance Hall
As door was opened, smoke concentration in the entrance hall $\underset{x}{*} 17.4$ was almost the same level to that of in fire room. No measurement was $\frac{\pi}{17}$ carried out on $\mathrm{CO}, 3$ $\mathrm{CO} 2$ and $\mathrm{O} 2$ gas concentrations. In contrast to this, as door 1 was closed, smoke concentration of $\mathrm{Cs}=0.1 / \mathrm{m} \quad$ was observed at around $120 \mathrm{~cm}$ which almost corresponds

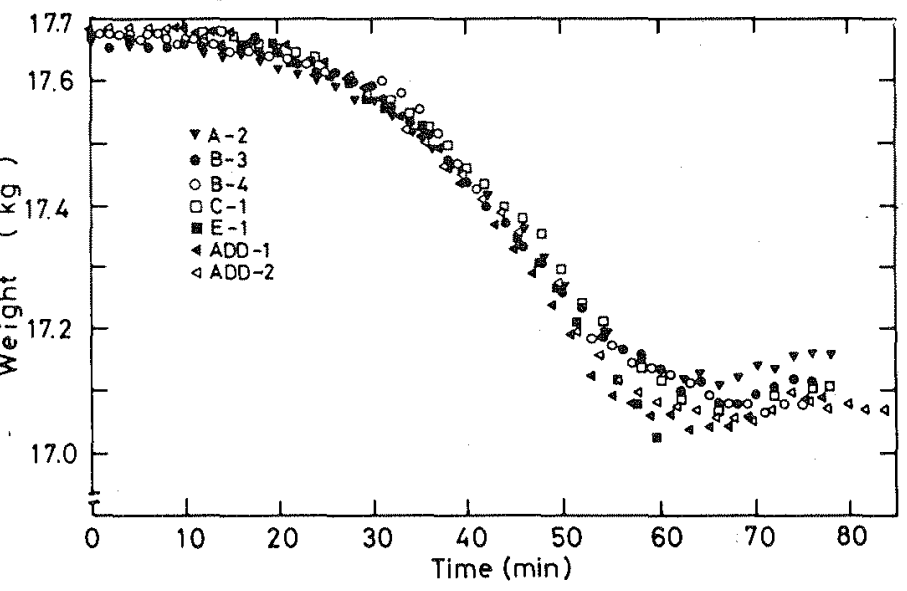

Figure 3 Weight loss of mockup cushions versus time.

to the height of eyes and nose and maximum temperature rise of 3-5 $\mathrm{K}$ was obtained at the end of flaming duration. However, thicker Table 2 SMOKE CONCENTRATION $\left(\mathrm{Cs} ; \mathrm{m}^{-1}\right)$ smoke of about $1 / \mathrm{m}$ was obtained

\begin{tabular}{|c|c|c|c|c|}
\hline $\begin{array}{l}\text { FIRE } \\
\text { ROOM }\end{array}$ & $P_{Q_{R}}$ & $\begin{array}{c}\text { ENTRANCE } \\
\text { HALL }\end{array}$ & $\begin{array}{c}{ }_{0} 0_{k} \\
20{ }^{2} 3\end{array}$ & CORRIDOR \\
\hline $\begin{array}{l}C s=4 \sim 5 \\
C s=2 \sim 2.4 \\
\text { after }\end{array}$ & $\begin{array}{l}O \\
P \\
E \\
N\end{array}$ & 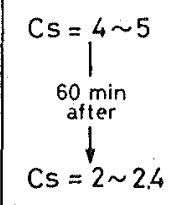 & $\begin{array}{l}\mathrm{C} \\
\mathrm{L} \\
\mathrm{O} \\
\mathrm{S} \\
\mathrm{E}\end{array}$ & $C s=0$ \\
\hline $\begin{array}{l}C s=4 \sim 5 \\
C 0 \text { min } \\
\text { after } \\
C s=2 \sim 2.4\end{array}$ & $\begin{array}{l}\mathrm{C} \\
\mathrm{L} \\
\mathrm{O} \\
\mathrm{S} \\
\mathrm{E}\end{array}$ & $\begin{array}{c}\mathrm{Cs}=\sim 0.1 \\
(\max .0 .7 \sim 1.2) \\
\begin{array}{c}60 \min \\
\text { after } \\
\mathrm{Cs}=0.7 \sim 1.2\end{array} \\
\end{array}$ & $\begin{array}{l}\mathrm{C} \\
\mathrm{L} \\
\mathrm{O} \\
\mathrm{S} \\
\mathrm{E}\end{array}$ & $C s=0$ \\
\hline $\begin{array}{c}\mathrm{Cs}=4 \sim 5 \\
\mathrm{Cs}=2 \sim 2.4 \\
\begin{array}{c}60 \min \\
\text { after }\end{array} \\
\end{array}$ & $\begin{array}{l}C \\
L \\
0 \\
S \\
E\end{array}$ & $\begin{array}{c}\mathrm{Cs}=\sim 0.1 \\
(\max .0 .7 \sim 1.2) \\
\begin{array}{c}60 \text { min } \\
\text { after }\end{array} \\
\mathrm{Cs}=0.7 \sim 1.2\end{array}$ & $\begin{array}{l}O \\
P \\
E \\
N\end{array}$ & $\begin{array}{c}C s=0.1 \sim 0.2 \\
C s=0.7 \sim 0.8\end{array}$ \\
\hline
\end{tabular}
under the ceiling and above the floor. CO and $\mathrm{CO} 2$ gas concentration were almost $1 / 5$ to the ones in fire room in smoldering duration. After $60 \mathrm{~min}$, an increase of smoke concentration of $0.7-1.2 / \mathrm{m}$ was observed, which was almost $1 / 3-1 / 2$ of the concentration in fire room. Concentrations of $\mathrm{CO}$ and $\mathrm{CO} 2$ increased to $0.063-0.064 \%$ and to $0.7-0.9 \%$, respectively. The apparent dilution ratio between fire room and entrance hall depend on gas concentration change was about $1 / 3$ which is almost equal ratio to the one estimated by $\mathrm{Cs}$ change. 3-5 K of temperature rise was observed at the end of smoldering duration, and in flaming duration about $40 \mathrm{~K}$ was obtained under the ceiling indicating the triangle shape distribution with about $0.2 \mathrm{~K} / \mathrm{cm}$ along the vertical direction. If there were no apparent natural convection and flow in an entrance hall, it is almost certain that 
the hall which is partitioned even by a simple wooden door is safe enough to use as an evacuation route.

\section{Middle Corridor}

The smoke leakage from the entrance door was hardly measurable even in the flaming duration which gave about $5 \mathrm{mmAq}$ pressure difference between fire room and corridor.

In contrast to this, when entrance door was opened, smoke concentration at the front of entrance door was about $0.1-0.2 / \mathrm{m}$ and peak concentrations of $\mathrm{CO}$ gas was $0.011-0.013 \%$ and of $\mathrm{CO} 2$ was $0.053-0.06 \%$ which were about $1 / 3$ to the ones in entrance hall, and the ratio of $\mathrm{CO} / \mathrm{CO} 2$ of 0.2 was conserved in smoldering duration. After $60 \mathrm{~min}$, smoke concentration increased to $0.7-0.8 / \mathrm{m}$ with time delay of about $2 \mathrm{~min}$. Little dilution on smoke concen-

Table 3 GAS CONCENTRATIONS ( $\%)$

\begin{tabular}{|c|c|c|c|c|}
\hline $\begin{array}{l}\text { FIRE } \\
\text { ROOM }\end{array}$ & $\mathrm{D}_{0}$ & $\begin{array}{c}\text { ENTRANCE } \\
\text { HALL }\end{array}$ & $\mathrm{D}_{\mathrm{O}_{\mathrm{R}}}$ & CORRIDOR \\
\hline $\begin{aligned} \mathrm{CO} & =0.2 \\
\mathrm{CO}_{2} & =1.0 \\
\mathrm{O}_{2} & =20.3 \\
60 \mathrm{~min} & \\
\text { after } & \\
\mathrm{CO} & =0.2 \\
\mathrm{CO}_{2} & =2.0 \\
\mathrm{O}_{2} & =18.5\end{aligned}$ & $\begin{array}{l}\mathrm{C} \\
\mathrm{L} \\
\mathrm{O} \\
\mathrm{S} \\
\mathrm{E}\end{array}$ & $\begin{aligned} \mathrm{CO} & =0.037 \\
\sim & 0.047 \\
\mathrm{CO}_{2} & =0.20 \\
\mathrm{O}_{2} & =20.7 \\
60 \mathrm{~min} & \sim 20.8 \\
\text { after } & \\
\mathrm{CO} & =0.063 \\
\mathrm{CO}_{2}=0.0 .064 & =0.9 \\
\mathrm{O}_{2} & =20.03\end{aligned}$ & $\begin{array}{l}\mathrm{C} \\
\mathrm{L} \\
\mathrm{O} \\
\mathrm{O} \\
\mathrm{S}\end{array}$ & $\begin{array}{l}\mathrm{CO}=0.0048 \\
\mathrm{CO}_{2}=0.048 \\
\mathrm{O}_{2}=20.81 \\
60 \mathrm{~min} \\
\text { after } \\
\mathrm{CO}=0.0056 \\
\mathrm{CO}_{2}=0.069 \\
\mathrm{O}_{2}=20.78\end{array}$ \\
\hline $\begin{aligned} & \mathrm{CO}=0.2 \\
& \mathrm{CO}_{2}=1.0 \\
& \mathrm{O}_{2}=20.3 \\
& 60 \mathrm{~min} \\
& \text { after } \\
& \mathrm{CO} \approx 0.2 \\
& \mathrm{CO}_{2}=2.0 \\
& \mathrm{O}_{2}=18.5\end{aligned}$ & $\begin{array}{l}\mathrm{C} \\
\mathrm{L} \\
\mathrm{O} \\
\mathrm{S} \\
\mathrm{E}\end{array}$ & $\begin{aligned} & \mathrm{CO}=0.037 \\
& \sim 0.047 \\
& \mathrm{CO}_{2}=0.20 \\
& \mathrm{O}_{2}=20.7 \\
& 60 \mathrm{~min} \\
& \mathrm{after} \\
& \mathrm{CO}=0.063 \\
&=0.064 \\
& \mathrm{CO}_{2}=0.7-0.9 \\
& \mathrm{O}_{2}=20.03\end{aligned}$ & $\begin{array}{l}0 \\
P \\
E \\
N\end{array}$ & $\begin{array}{l}\mathrm{CO}=0.011 \\
-0.013 \\
\mathrm{CO}_{2}=0.053 \\
-0.060 \\
\mathrm{O}_{2}=20.9 \\
60 \mathrm{~min} \\
\text { after } \\
\mathrm{CO}=0.023 \\
\mathrm{CO}_{2}=0.11 \mathrm{n} 0.12 \\
\mathrm{O}_{2}=20.83\end{array}$ \\
\hline $\begin{aligned} \mathrm{CO} & =0.2 \\
\mathrm{CO}_{2} & =1.0 \\
\mathrm{O}_{2} & =20.3 \\
60 \mathrm{~min} & \\
\text { after } & \\
\mathrm{CO} & =0.2 \\
\mathrm{CO}_{2} & =2.0 \\
\mathrm{O}_{2} & =18.5\end{aligned}$ & $\begin{array}{l}O \\
P \\
E \\
N\end{array}$ & $\begin{array}{l}\text { NOT } \\
\text { MEASURED }\end{array}$ & $\begin{array}{l}\mathrm{C} \\
\mathrm{L} \\
\mathrm{O} \\
\mathrm{S} \\
\mathrm{E}\end{array}$ & $\begin{aligned} & \mathrm{CO}=0.0048 \\
& \mathrm{CO}_{2}=0.048 \\
& \mathrm{O}_{2}=20.81 \\
& 60 \mathrm{~min} \\
& \text { after } \\
& \mathrm{CO}=0.0056 \\
& \mathrm{CO}_{2}=0.069 \\
& \mathrm{O}_{2}=20.78\end{aligned}$ \\
\hline
\end{tabular}
tration was observed with it parts when it was driven to corridor from entrance hall. Smoke moved so slowly with arifting and conserved its distribution like a smokecloud. This kind of smoke movement was also reported as the movement in a long corridor (ref.3). Table 2 shows the almost the same smoke concentrations were observed in entrance hall and in corridor after flaming, and these are almost $1 / 3-1 / 2$ to the one in fire room. The upper limit of smoke concentration which begins to give serious emotional fluctuation to residents is about $\mathrm{Cs}$ of 0.1 $0.15 / \mathrm{m}$ (ref. 4), and $\mathrm{Cs}$ of $0.7-0.8 / \mathrm{m}$ gives walking speed of $0.3-0.7 \mathrm{~m} / \mathrm{sec}$ (ref. 5). This tells that there is a strong fear of smoke blocking against the evacuation in midde corridor when door was opened. Closing of door 2 , independent of door 1 opened or closed, produced about $1 / 30$ co gas concentration relative to one in fire room. As can be seen from Table 3 , this concentration level may give an enough time to evacuation before toxic gases rise up to serious levels. As the closed entrance door without air tight material gave the smoke concentration of about $0.3-0.5 / \mathrm{m}$ about $10 \mathrm{~min}$ before the flaming period. The smoke contaminated region was found at least $4 \mathrm{~m}$ for both side from the entrance door. Little temperature rise was measured in corridor even in the flaming duration. Therefore, these phenomena strongly suggested that it is necessary to set the auto door closer and air tight material to the entrance door. 
Pressure change and air ventilation rate

In the smoldering duration, very little pressure difference was obtained, but pressure jumped up to about $5 \mathrm{mmAq}$ based on alcohol burning. This high pressure difference resulted in a

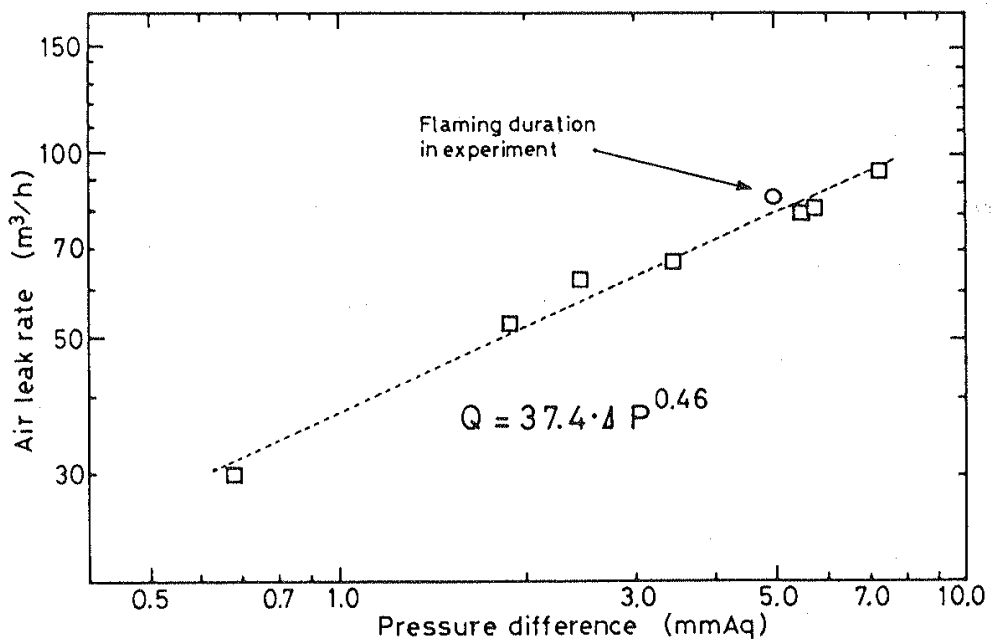

Figure 4 Logarithmic plots of air leak rate against pressure difference between fire room and corridor.

greater ventilation rate through many small openings, then negative pressure difference of about $-10 \mathrm{mmAq}$ was given to the fire room depend on 02 consumption. Air exchange rate during smoldering and flaming was monitored using a tracer gas. The air exchange rate estimated by the tracer gas concentration change was $1.1 / \mathrm{h}$ for smoldering and $1.8 / \mathrm{h}$ for flaming for this facility. The relationship between pressure difference and air volume of leakage was tested preliminarily with using a fan with controller and a Venturi tube. This gave the relationship of: $Q=37.4 \mathrm{P}$, as shown in Fig.4. Air exchange rate in flaming duration is shown with a circle in Fig. 4.

No difference was found in the leakage behavior of smoke through/around the entrance door with or without the pressure difference which was given to estimate the natural wind effect.

\section{Working time of fire detectors}

The working times of smoke fire detectors estimated based on their outputs and are shown in Fig. 5. These figures tell the apparent tendency that L.S.D. worked a little earlier than I.S.D. did in fire room, and roughly the opposite tendency was obtained in entrance hal1. And in corridor, the I.S.D. worked in a few cases of entrance door opened, and of the door without air tight material. These working behaviors may come from the difference in size distribution of smoke particles which was induced by the difference of diffusive characteristics depend on particle size. Number concentration and mobility of larger size smoke particles is small relative to smaller ones (ref. 6). And for smaller size particles, I.S.D. can work earlier relative to L.S.D. (ref. 7). It is plausible that these situation gave the earlier detecting 
time to I.S.D. relative to L.S.D. In this series of experiments, observation windows which connects to outside were closed except E-1. An attention should be called on that the ambient air in fire room, in entrance hall, and in corridor was very still, no appa- L rent air flow was given except the flows induced by flame or. by pressure difference. These caused no excess driving force when particles gets into the labyrinth of L.S.D. In real case, air flow induced by natural and/or forced convection give the adequate movement to particles. Therefore, no significant difference on working times is expected between both types of smoke detector when they mounted to the ceiling of entrance hall which connects to fire room.

No heat detector worked in smoldering duration even in fire room. It was apparent that smoke detectors are advantageous to heat detector on a smoldering fire.

\section{(b) Real Furniture Fire}

In smoldering duration, the changes of temperature, smoke concentration, gas concentration depend on growth of fire were almost as same as ones which were observed for
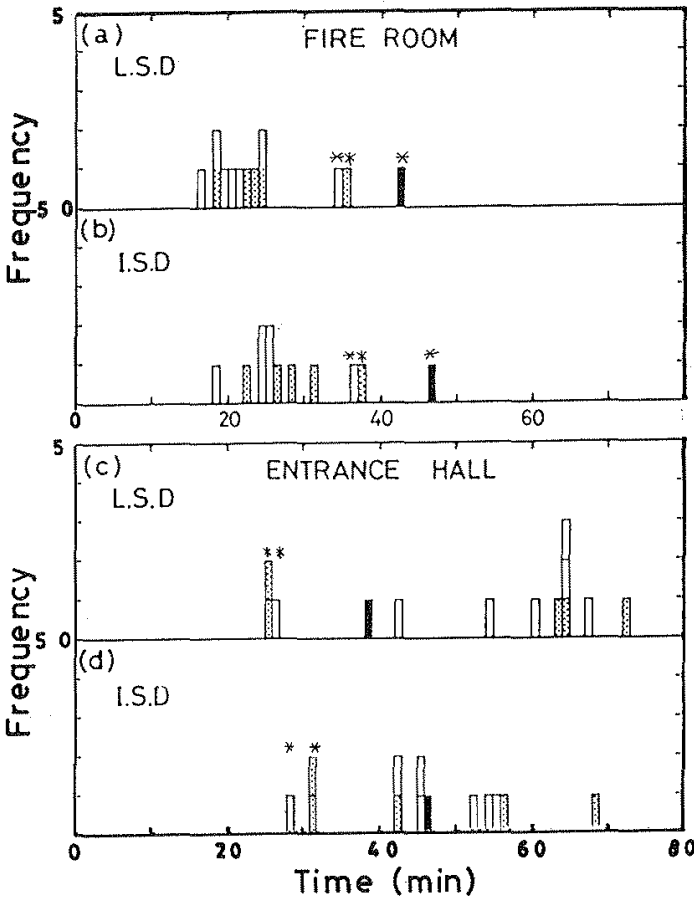

Figure 5 Frequency of smoke detector of light scattering type (L.S.D) and ionization type (I.S.D) in fire room and in entrance hal1. Histogram with * is door 2 open, with mesh screen is pressure difference given, and with rigid one is real furniture fire source. mockup cushions Eire. At around $50 \mathrm{~min}$, smoldering zone developed into the foam of back part of the sofa, then after past $60 \mathrm{~min}$, it reached to a small amount of alcohol which was set preliminarily to get a flaming combustion. Flaming combustion grew rapidly inside the back space of the sofa and at about $65 \mathrm{~min}$ developed to wallpaper and to other combustible materials. Rapid temperature rise was observed and which gave pressure difference of over $5 \mathrm{mmAg}$, which was beyond the range of our system. Hot dense smoky gas exhausted giving hiss through the gaps of aluminum sash of slide door. Combustible hot gas which arifted under ceiling burned toward down drawing a layer of 30 - $50 \mathrm{~cm}$ thick. This burning phenomena were observed at least twice in about $1 \mathrm{~min}$ before break down of slide door. Temperature, smoke concentration, and number concentration of particles covering $0.2-2.0 \mu$ by 5 steps of channel isolation were monitored in corridor. Increase of temperature and smoke concentration which were measured by employed system were hardly observed both in flaming duration and after flashover. Fig. 6 shows the 
number concentration of particles versus time. When entrance door was open, it is clear of smoke coming into corridor as shown in Fig. 6-(a). In contrast to this, as the entrance door closed, the number concentration of particles increased little till about 30 $\mathrm{min}$, and slightly increased for $30-40 \mathrm{~min}$. And at around $50 \mathrm{~min}$ and after, apparent increasing were obtained in each channels as shown in Fig.6-(b), (c). The measurable upper limit of the number concentration for covering range of $0.2-0.5 \mu$, was about $2 \times 10^{11} / \mathrm{m}^{3}$ depend on coincidence loss (ref. 8). Therefore, it is better to use the number concentration of channel 4 and channel 5 to compare the leakage performance. For example, the case of entrance door open, number concentration of $1.0-2.0$ u particles was 10 times greater than one in case of entrance door closed.

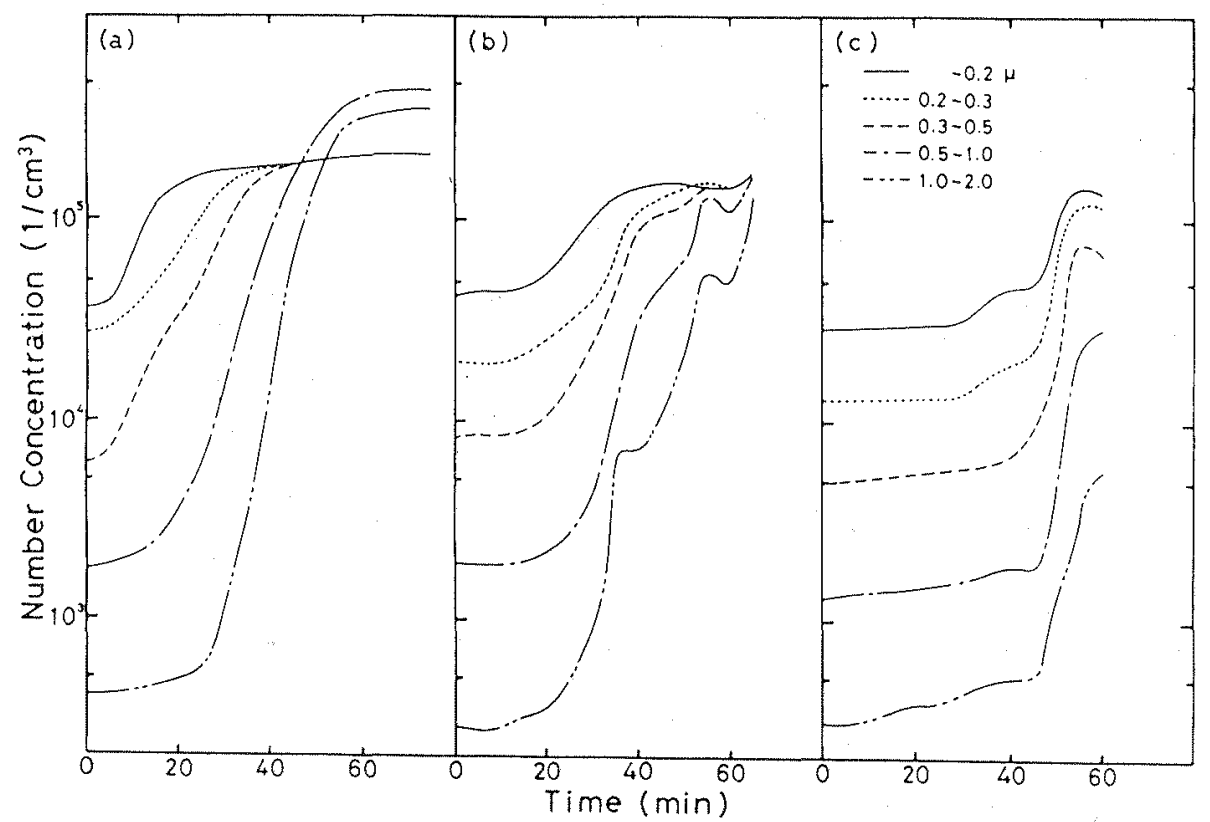

Figure 6 Time histories of number concentration of smoke particles, (a) Exp. A-2, (b) Exp. B-2 for mockup cushions and (c) Exp. $B-1$ of real

furniture fire.

5. Conclusion

In the middle corridor, smoke leakage from the entrance door(class A fire door with air tight material) was hardly observed even the fire room was pressurized as high as $5 \mathrm{mmaq}$ or more by fire. However, the door without air tight material permitted the smoke leakage of over $0.1 / \mathrm{m}$ of which concentration must give the disorientation to residents. Therefore, the key point of successful evacuation using a midale corridor depends on closing of the entrance door and installation of an auto door close and an air tight material. 
No difference was obtained with respect to the smoke leakage performance between inward and outward openable door with the pressure difference given between fire room and corridor. If the entrance door satisfy the smoke leakage performance as mentioned above, a criterion of door selection whether it opens inward or outward primarily depends on security performance and on the matter of convenience for usual use. However, it is preferable to adopt a outward panic door which installed in a middle corridor to confirm the compartmentation and evacuation.

It was hard to expect the early detecting of smoldering fire by heat detector. In the fire room, light scattering smoke detector worked earlier relative to ionization smoke detector, however the difference in the working time between them were not serious. Considering a development of fire growth from smoldering to flaming and a fire with flaming at its starting and also considering on the reduction of total number of detectors to be mounted to a residential compartment, ionization smoke detector is advantageous to the other detector as a residential fire detector except the consideration on the frequency of false alarm.

\section{Acknowledgments}

The authors wish to thank Mr. Takeda, chief official of Sci. univ. of Tokyo, and Mr. Endo, a member of Nohmi Bosai Ltd., for their kind help for the experiment. We thank Mr. Nishimoto, Mr. Yamanaka, and students of Kawagoe, Handa, and Ogahara laboratories for fully support of this experiment.

\section{References}

1) Babrauskas, V., NBS TECHNICAL NOTE 1103 Aug. (1979)

2) Kawagoe, $\mathrm{k}$., Mizuno, T., Private Communication

3) Handa, T., Hamada ,T., Fukaya, H., Sugawa, O., Kaneko, K., Furukawa, $Y$, and Endo, K.,

Bull. Jpn. Asso. Fire Sci. and Eng. vol.28, No.2 (1978)

4) Jin, T., J. Jpn. Asso. Fire Sci. and Eng. No.97 p44 (1975)

5) Jin, T., Bull. Jpn. Asso. Fire Sci. and Eng. vol.30, No. 1 p1 (1980)

6) Handa, T., and Sugawa, O., CIB Symp. III-5, TSUKUBA Aug. (1977)

7) Lee, T., and Mulholland, G., NBSIR 77-1312 (1977)

8) Handa, T., and Nagashima, T., Fire Flamm. vol.1 p265 (1977) 